\title{
MANAJEMEN WAKAF SEBAGAI PEMBIAYAAN BARANG PUBLIK DAN BARANG PUBLIK CAMPURAN DI INDONESIA
}

\author{
Nur Rachmat Arifina \\ a Islamic Economics Department, Faculty of Economics and Business, Universitas Islam Zainul \\ Hasan \\ Email: nurrachmatarifin05@gmail.com
}

\begin{abstract}
Introduction: This paper is to formulate a model for waqf invested in public goods and mixed public goods in Indonesia. This model is built on understanding the concept of waqf, learning from waqf institutions from the past and present and addressing the problem of perwakafan in Indonesia.

Methods: This research uses descriptive qualitative research with library method or library research. This research uses secondary data from the Indonesian Wakaf Agency (BWI), books, journals, newsletters, government reports and websites.

Results: Found that a return from the application of invested endowments could help state coffers in the form of public goods and mixed public goods. The overall process can be managed by waqf institutions as waqf nazdir who cooperate in supervising BWI (Badan Wakaf Indonesia) in using government waqf assets need to understand what should be spend required in accordance with syaraih rules.

Implications - This research shows how practical waqf can help the Government of Indonesia in financing public goods and mixed public goods. This indirectly indicates an alternative source of funding for these items. The application of waqf concept can learn and adapt from the model developed in this paper.

Originality - This paper tries to revive the function of waqf as a provider of public goods and public goods that vary from Islamic history. Inadvertently, this paper also introduces waqf as fiscal policy in Indonesia.
\end{abstract}

Keyword : Waqf, invested endowments, financing public goods and mixed public goods.

\section{PENDAHULUAN}

Pada masa Rasulullah SAW terdapat terdapat mempunyai tempat khusus untuk menyimpan harta, karena saat itu harta yang diperolehnya belum begitu banyak dan hartanya segera didistribusikan kepada rakyatnya. Adapun perkembangan Baitul Mal setelah masa Rasulullah SAW kemudian secara bertahap mulai dari Khalifah Abu Bakar dan diperluas pada masa Khalifah Umar, Utsman dan Ali. Akibat dari adanya banyak penaklukan wilayah serta umat Islam mulai mengenal ilmu tata negara pemerintahan Persia, maka hal tersebut mulai diterapkan pada Baitul Mal. Selama pemerintahan Khalifah Ali, sistem administrasi Baitul Mal di tingkat pusat maupun lokal sudah berjalan 
baik. Hal ini terlihat dari adanya kerjasama antara pusat dan daerah, sehingga pendapatan Baitul Mal mengalami surplus dan kelebihannya dibagikan secara proporsional ${ }^{1}$.

Pengelolaan Baitul Mal kemudian diteruskan oleh Daulah Islamiyah, hingga akhirnya kekhilafahan Islam runtuh pada tahun 1924 M. Baitul Mal pada masa Daulah Islamiyah merupakan lembaga atau institusi negara sebagai tempat dan pengelolaan dana umat dari pengumpulan sumber pendapatan hingga pengalokasian belanja negara sesuai dengan kaidah Islam.

Adapun alur penyusunan APBN Indonesia yaitu Pemerintah bersama Dewan Perwakilan Rakyat (DPR) akan membahas dan menyepakati Anggaran Pendapatan dan Belanja Negara (APBN) dengan memperhatikan pertimbangan Dewan Perwakilan Daerah (DPR) RI. Hal ini tentu saja berbeda dengan pengaturan dan pengelolaan Baitul Mal pada masa Daulah Islamiyah seperti Pemerintah Indonesia yang menggunakan kebijakan defisit sebagai alat untuk menstabilkan perekonomian.

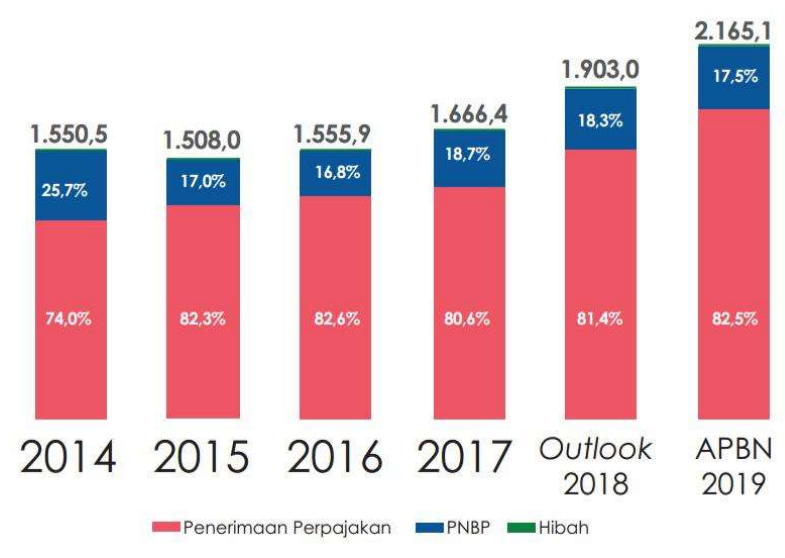

\section{Gambar 1.1 Perkembangan Penerimaan Pendapatan APBN Indonesia Tahun 2014 - 2019 (triliun rupiah)}

Sumber: Kementerian Keuangan RI (2019)

Berdasarkan Gambar 1.1 menunjukkan bahwa penerimaan pajak menjadi sumber utama pendapatan negara dalam membiayai anggaran belanja negara, dimana kontribusi perpajakan terus meningkat menjadi $82,5 \%$ selama lima tahun terakhir. PPh dan PPN merupakan kontribusi utama dalam pendapatan negara yakni sebesar $50,1 \%$ dan $36,7 \%$ terhadap penerimaan perpajakan. Kebijakan perpajakan ini berdasarkan asas keadilan mendorong daya saing industri dan kemudahan berusaha. Data perkembangan sumber penerimaan pendapatan negara Indonesia menunjukkan perbedaan dengan sumber utama pendapatan di Baitul Mal pada masa Daulah Islamiyah.

\footnotetext{
${ }^{1}$ Karim, A. Ekonomi Makro Islam. (Jakarta: PT. Rajawali Press, 2017)
} 
Tujuan dari penelitian ini, penulis menunjukkan wakaf merupakan istrumen yang dugunakan pada zaman Rasulullah sebagai pemasukan Kas Negara yang dikelola Baitul Mal, di Indonesia dengan mayoritas beragama muslim dan menjadikan wakaf sebagai barang publik dan barang publik campuran dan menunjukkan bagaimana wakaf sebagai peningkatan dalam Insdutri keuangan dengan basis transparan sehingga wakif ikut andil dalam mengetahui perkembangan harta wakafnya, konsep wakaf merupakan pelestarian yang mana harta wakaf yang yang dibelanjakan oleh negara untuk dikembangkan proses wakaf tersbut dan tidak mengurangi nilai harta wakaf tersebut

Negara Indonesia yang beragam suku dan bangsa memiliki iktikad untuk mensejahteraan masyarakat dan ummatnya, maka isntrumen harta wakaf tanah yang terdaftar di BWI sejumlah 4.359.443.170,00, maka Menjadi tantangan bagi pemerintah untuk memaksimal harta wakaf yang ada digunakan untuk Financing dalam menjalankan proses penerimaaan dan pengeluaran Kas Negara. Pengeluaran pemerintah perlu memahami apa yang harus akan diperbelanjakan diwajibkan sesuai dengan kaidah syaraih, pada tahap awal tulisan ini memaksimal harta wakaf yang diiinvestasikan selamanya tersebut dapat digunakan untuk perputaran keuangan Kas Negara dengan menimalisir hutang. Seperti berpendapat kemudian, konsep dari wakaf adalah pelestarian Prinsip mana hanya kembali dari itu dibelanjakan.

\section{KAJIAN PUSTAKA \\ Wakaf dalam Islam}

Kata "Wakaf" berasal dari kata bahasa Inggris "Wact" dalam bahasa Arab "Waqafa". bermakna "menahan" atau "berhenti" atau "diam ditempat". Kata "Waqafa-Yaqifu-Waqfa" memiliki persaman arti dengan "Habasa-Yahbisu-Tahbisan" dalam syariat, wakaf bermakna menahan pokok dan mendermakan buah atau mangalirkan manfaatnya di jalan Allah 2. Menurut bahasa, wakaf diartikan dengan menahan, sedangkan menurut syara' diartikan dengan menahan harta tertentu yang dapat dipindahkan yang mungkin untuk dimanfaatkan sesuai dengan utuhnya barang dan menghentikannya utnuk dialokasikan ke arah kebaikan demi mendekatkan diri pada Allah ${ }^{3}$. Kata al-Waqf dalam Arab mengandung beberapa pengertian :

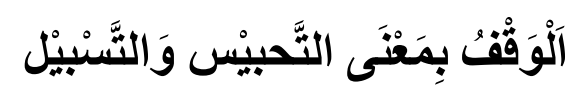

Menahan, menahan harta untuk diwakafkan, tidak dipindah milikan

\footnotetext{
2 Sabiq S, Fiqih Sunnah 5, (Jakarta : Tinta Abadi Gemilang, 2013).

${ }^{3}$ Aby Zain Ibnu, Fathul Qarīb 3 Bahasa, (Kediri : Zamzam Sumber Mata Air Ilmu, 2016)
} 
Perbedaan Para ulama dalam mengutarakan pendapatnya yang memberi pengertian wakaf. Perbedaan tersebut membawa dan menimbulkan berbeda pada hukum yang ditimbulkan .

\section{Penggunaan wakaf dalam pembiayaan barang publik dan barang publik campuran}

Penggunaan barang publik dan barang publik campuran dapat diterapkan dengan konsep wakaf dalam sejarah Islam, Nabi Muhammad menerapkan konsep wakaf untuk finance untuk pertahanan, dan Utsman bin Affan telah membeli sebuah sumur di Madinah untuk membuat air bebas minum untuk seluruh umat Islam. Kedua kasus wakaf terjadi setelah Nabi Muhammad saw hijrah ke Madinah, setelah itu menjadi dinegara Islam pertama 5 .

Madinah adalah negara yang memiliki keluasan relatif kecil yang jelas wakaf untuk pelayanan barang publik saat itu. Namun, wakaf untuk layanan dari barang-barang ini masih dikatakan sesuai dengan wilayah Muslim. Sebagai soal fakta, jumlah harta wakaf meningkat sehingga Diwan al-Ahbas dibentuk selama Kekhalifahan Umayyah di tingkat negara untuk menghindari penyalahgunaan ${ }^{6}$. Dalam era ini, wakaf untuk pendidikan yang sangat menuntut dan dengan demikian menjamur yang termasuk pembangunan perpustakaan dan sekolah, pendanaan dari guru dan mensponsori para sarjana dan mahasiswa ${ }^{7}$. Ini mungkin adalah bentuk paling awal dari wakaf untuk barang publik campuran.

Pada saat kekhalifahan Abbasiyah muncul, Khalifah Al Ma'mun telah memberikan kesehatan dan pendidikan melalui sarana wakaf, dana investasi wakaf bahkan mengatur terdiri dari lahan pertanian, bisnis dan bangunan sewa perumahan untukfinance untuk biaya operasional rumah sakit 8 .

Hasil penelitian Ambrose 2018 mengatakan Harta wakaf ini bernilai menunjukkan di sini adalah kenyataan bahwa lahan pertanian dan bangunan tempat tinggal memiliki risiko lebih rendah daripada bisnis. resiko yang terjadi hanya ketika terjadi bencana alam atau ketika warga tidak bisa membayar sewa untuk beberapa alasan. Yang terakhir, memiliki risiko kerugian dan kebangkrutan.

Oleh karena itu timbul pertanyaan: Mengapa risiko Khalifah berinvestasi dalam bisnis juga? Mungkin Khalifah menyadari bahwa risiko dapat diminimalkan dengan berinvestasi di beberapa jalan diperbolehkan, sehingga memastikan sumber yang berkelanjutan keuangan untuk rumah sakit. dana investasi wakaf tersebut sangat menyerupai teori

\footnotetext{
${ }_{4}$ Direktorat Pemberdayaan Wakaf Kementrian Agama RI. Retrieved from https://www.bwi.or.id/. Diakses 29 Mei 2019.

${ }^{5}$ Gil, M, “The earliest waqf foundations”, Journal of Near Eastern Studies, Vol. 57 No. 2, pp. 125-140, 1998.

6 Mohsin, M.I.A., CashWaqf: A New Financial Product, 1st ed., Pearson Malaysia Sdn Bhd, Kuala Lumpur,2009.

7 Mohsin, M.I.A., CashWaqf: A New Financial Product, 1st ed., Pearson Malaysia Sdn Bhd, Kuala Lumpur,2009.

${ }^{8}$ Kahf,M, Islamic Economics: The Charitable Sector, Ad Dawhah, Qatar 2014.
} 
portofolio, dimana risiko dapat diminimalkan dan kembali dioptimalkan dengan memegang diversi suatufied portofolio aset dengan tingkat risiko yang berbeda 9 . Bagaimanapun, fakta ini sangat menunjukkan bahwa wakaf Struktur merupakan fleksibel yang dapat berbentuk dalam konsep Syariah untuk menghasilkan pendapatan berkelanjutan. Hal ini tidak mengherankan bahwa wakaf kemudian dibuat untuk mendukung isntrumen fiskal lainnya dalam barang publik dan kategori barang publik campuran. Seperti yang terlihat pada periode akhir dari Kekhalifahan Abbasiyah, wakaf telah diberkahi untuk tujuan perawatan hewan, konseling masalah perkawinan, obatobatan dan melatih dokter baru 10 .

Pada awal Dinasti Ayyubiyah, wakaf menjadi kebijakan pemerintah yang dilengkapi dengan instrumen fiskal yang dibawa oleh Sultan Salahuddin, makanan, lembaga pendidikan, pemandian umum, kebun dan toko-toko adalah contoh dari sifat yang diberkahi oleh Sultan. Sama seperti Khalifah Al-Ma'mun, Sultan Salahuddin juga telah menciptakan harta dana wakaf untuk menjamin keberlajutan secara terus-menerus dari lembaga pendidikan. Bahkan, wakaf sebagai kebijakan pemerintah menjadi warisan yang diawetkan oleh Kekaisaran Ottoman, begitu banyak sehingga sistem wakaf mencapai puncaknya pada jaman itu. Diperkirakan bahwa pendapatan dari wakaf menyamai sepertiga dari Ottoman's pendapatan pada akhir abad kedelapan belas ${ }^{11}$. Penggunaan wakaf begitu luas bahwa itu melayani sekolah, didukung pensiun pelaut, dibayar kapal komuter, didanai pertahanan kota, air yang disediakan, dibayar pajak untuk rekan-rekan senegara dan menciptakan kesempatan kerja ${ }^{12}$. Bahkan orang-orang Kristen dan Yahudi pada periode Ottoman wakaf didirikan menyerupai wakaf meliputi aset seperti gudang, toko, rumah, apartemen dan bahkan kebun-kebun dan kebun-kebun anggur.

Keberhasilan wakaf tersebut dalam sejarah memberikan pelajaran berharga bagi implementasi modern yang sukses wakaf. Kami belajar bahwa wakaf telah berhasil didanai barang publik dan barang publik campuran di masa lalu, bahkan telah menjadi bagian dari kebijakan pemerintah selama Dinasti Ayyubiyah. Hal ini menunjukkan bahwa sangat mungkin untuk menggunakan implementasi wakaf yang sama saat ini. Namun, literatur merekomendasikan bahwa lembaga wakaf akan corporatized tersebut untuk menjadi sukses dan berkelanjutan. Dalam hal ini, wakaf juga harus diinvestasikan dengan bijaksana untuk menghasilkan profit.

\section{Konsep dan pemerintahan Syariah hukum wakaf}

\footnotetext{
${ }^{9}$ Brealey, R.A., Myers, S.C. and Allen, F, Principles of Corporate Finance, McGraw Hill Irwin, New York, NY, 2011.

${ }^{10}$ Mohsin, M.I.A., CashWaqf: A New Financial Product, 1st ed., Pearson Malaysia Sdn Bhd, Kuala Lumpur,2009.

${ }^{11}$ Kuran, T, "The provision of public goods under Islamic law: origins, impact, and limitations o the waqf system", Law\& Society Review, Vol. 35 No. 4, pp. 841-898, 2001.

12 Babacan, M, "Economics of philanthropic institutions, regulation and governance Turkey", Journal of Economic and Social Research, Vol. 13 No. 2, pp. 61-89, 2011.
} 
Wakaf dapat dilihat sebagai anugerah bagi negara Islam. Wakaf, dapat diartikan "memegang properti tertentu dan melestarikan untuk con yangfined benefit filantropi tertentu dan melarang penggunaan atau disposisi luar spesifik yang tujuan ${ }^{13}$. Sementara definisi wakaf dari perspektif ekonomi sebagai "mengalihkan dana (dan sumber daya lainnya) dari konsumsi ke investasi mereka dalam aktiva produktif yang menyediakan baik hak pakai hasil atau pendapatan untuk konsumsi masa depan oleh individu atau kelompok individu". Itu adalah praktek yang Nabi Muhammad SAW mendorong yang dapat dilihat dari hadits ini khusus dalam Sahih Muslim:

Umar mengakuisisi lahan di Khaibar. Umar datang kepada Rasulullah SAW dan berkata "Saya mendapatkan harta dan belum pernah aku mendapatkan harta yang lebih berharga darinya. Bagaimana Tua memerintahkan tentangnya ? Beliau bersabda : "Jika kamu mau, kamu shadaqahkan (hasilnya)". Maka Umar menshadaqahkannya, dimana tidak dijual pepohanannya tidak juga dihibahkannya dan juga tidak diwariskannya, (namun dia manshadaqahkan harta itu) untuk para fakir, kerabat, untuk membebaskan budak fii sabilillah (dijalan Allah), untuk menjamu tamu dan ibnu sabil. Dan tidak dosa bagi orang yang mengurusnya untuk memakan darinya dengan cara yang ma'ruf (benar) dan untuk memberi makan teman-temanya asal bukan untuk menimbunnya

Kata sedekah dalam hadits berarti amal, dan amal merupakan bagian dari ekonomi. Oleh karena itu, wakaf juga merupakan bagian dari sektor yang sama tetapi dengan karakteristik tersendiri yang berbeda, yaitu, tidak bisa dijual, diwariskan atau diberikan sebagai hadiah. Seperti telah dinyatakan dalam hadits spesifik lebih lanjut dalam prinsip-prinsip wakaf sebagai tidak dapat dibatalkan, tidak dapat dicabut dan lamanya. Tidak dapat dibatalkan dimaknai ketika aset dinyatakan sebagai wakaf, tetap sebagai wakaf selamanya. Sementara itu, tidak dapat dicabut menyatakan bahwa wakaf tidak boleh dijual, diwariskan atau diberikan sebagai hadiah. Ini sebenarnya adalah sebuah interpretasi langsung dari hadits disebutkan sebelumnya. Bahwasanya wakaf harus tetap secara permanen utuh, tidak bisa tahan lama dan tidak bisa berhenti dengan mudah ${ }^{14}$.

Akan tetatapi prinsip-prinsip ini tidak selamanya dapat sesuai dalam pelaksanaannya. Sejalan dengan madzhab Maliki, berpendapat bahwa wakaf sementara juga harus dilakukan diperbolehkan dalam kasus di mana pendiri wakaf secara eksplisit menyatakan begitu, atau tujuannya adalah sementara. Meskipun nilai-nilai volatil mereka, uang tunai, saham, unit trust dan bentuk lain dari pihak keuangan yang cocok untuk wakaf abadi. kesesuaian ini menyajikan kesempatan bagi kelas menengah dan mungkin lebih rendah juga memberkati wakaf, dinyatakan dalam Mohsin dan Çizakça, Imam Zufar dari

\footnotetext{
${ }^{13}$ Kahf,M, Islamic Economics: The Charitable Sector, Ad Dawhah, Qatar 2014.

14 Mohsin, M.I.A., Cash Waqf: A New Financial Product, 1st ed., Pearson Malaysia Sdn Bhd, Kuala Lumpur,2009.
} 
Madzhab Hanafi menyetujui uang tunai wakaf abadi. Sementara itu Mazhab Shafi'e, Maliki dan Hanbali melihat segala sesuatu dengan penjualan yang valid dan dapat diperpanjang kadang-kadang oleh hak pakai hasil atau sebaliknya, dapat diubah menjadi wakaf 15.

\section{METODE PENELITIAN}

Jenis penelitian yang digunakan dalam penelitian ini adalah penelitian kepustakaan atau library research. Penelitian library research, yaitu penelitian yang dilaksanakan dengan menggunakan literatur (kepustakaan), baik berupa buku, catatan, maupun laporan hasil penelitian dari penelitian terdahulu ${ }^{16}$. Sebagaimana pemikiran M. Iqbal Hasan, studi dokumentasi adalah tehnik pengumpulan data yang tidak langsung ditujukan pada sebuah penelitian, namun melalui dokumen. Dokumen yang digunakan dapat berupa buku harian, surat pribadi, laporan, notulen rapat, catatan khusus dalam pekerjaan sosial dan dokumen lainnya ${ }^{17}$. Penelitian melalui pendekatan kepustakaan merupakan penelitian yang dilakukan melalui pengumpulan data atau karya tulis ilmiah yang memiliki tujuan sama dengan objek penelitian yang bersifat kepustakaan atau telaah yang dilakasanakan untuk memecahkan suatu masalah melalui telaah kritis dan mendalam terhadap bahan-bahan pustaka yang relevan. Data tersebut dapat diperoleh dari berbagai bentuk informasi seperti buku, jurnal ilmiah, data publikasi statistika serta sumber lainnnya yang relevan dengan penelitian, Penelitian ini menggunakan pendekatan penelitian kualitatif, pendekatan kualitatif adalah dalam bentuk kata-kata, skema, dan gambar. ${ }^{18}$

\section{HASIL DAN PEMBAHASAN}

\section{Isu-isu penerapan wakaf di Indonesia}

Konsep wakaf tidak hanya melihat penerapan secara historis saja, sistem penerapan wakaf di Indonesia didominasi harta wakaf yang berbentuk sekolah masjid, dan kuburan, sehingga perlu adanya pengembangan harta wakaf yang tidak hanya berbentuk itui-itu saja dan menimbulakan tidak efektif harta wakaf, maka wakaf Indonesia perlu untuk ditinjau sebagai berikut :

a. Kesadaran masyarakat tentang wakaf filantropis

Ada beberapa bukti yang menunjukkan bahwa Muslim Indonesia dibatasi pandangan tentang wakaf. Kebanyakan hanya berasumsi bahwa wakaf dapat diberkahi hanya untuk tujuan pembangunan masjid, kuburan pemeliharaan dan bentuk-bentuk lain dari wakaf

\footnotetext{
15 Mohsin, M.I.A., CashWaqf: A New Financial Product, 1st ed., Pearson Malaysia Sdn Bhd, Kuala Lumpur,2009.

${ }^{16}$ M. Iqbal Hasan. 2002. Pokok-pokok Materi Metodologi Penelitian dan Aplikasinya. Bogor: Ghalia Indonesia. h. 89

17 Ibid, h. 89

18 Sugiyono. 2013. Metode Penelitian Kuantitatif Kualitatif dan R\&D. Bandung: Alfabeta h. 79
} 
keagamaan ${ }^{19}$. Namun, dari baru-baru ini, beberapa upaya telah dilakukan untuk mengubah situasi ini. Untuk satu, pemerintah telah membentuk Lembaga Nadzir berbentuk yayasan untuk meningkatkan pembangunan sosial-ekonomi masyarakat Muslim di Indonesia. lembaga nadzir wakaf berbagai macam bentuk diantaranya Lembaga ZISWAF (Zakat Infaq Wakaf dan Shadaqah), BMT, Yayasan dll sebagai membantu dalam pengelolaan harta wakaf. Melalui lembaga-lembaga tersebut diawasi oleh Badan Nasional yang mengesahkan dan mengawasu harta wakaf yakni BWI (Badan Wakaf Indonesia), pemerintah mengalokasikan anggaran untuk pengembangan wakaf publik di seluruh Indonesia beberapa di antaranya meningatkan ekonomi ummat. Namun, untuk mengukur kinerja dan perkembangan harta wakaf membutuhkan kesadaran masyarakat wakaf filantropis.

b. Peningkatan nilai wakaf

Pengelolaan harta wakaf dalam mengalokasikan sejumlah anggaran pemerintah untuk wakaf menyebabkan berkembangnya lebih lanjut dari pengeluaran pemerintah. Berkembang pengeluaran pemerintah adalah masalah berulang diIndonesia sejak terjadi krisis keuangan pada tahun 1997/1998. ). Dalam konteks negara Indonesia, amalan wakaf sudah dilaksanakan oleh masyarakat Muslim Indonesia sejak sebelum merdeka. Oleh karena itu pihak pemerintah telah menetapkan Undang-undang khusus yang mengatur tentang perwakafan di Indonesia, yaitu Undang-undang nomor 41 tahun 2004 tentang Wakaf. Untuk melengkapi Undang-undang tersebut, pemerintah juga telah menetapkan Peraturan Pemerintah nomor 42 tahun 2006 tentang Pelaksanaan Undang-undang nomor 41 tahun 2004. Pada saat ini pemerintah Indonesia sedang menggalakkan beberapa gerakan wakaf kemartabatan kesejahteraan, wakaf saham, wakaf profesi, wakaf ansuransi syariah dan bekerjasama bersama MPR dan BI.

Jumlah Tanah Wakaf Seluruh Indonesia

\begin{tabular}{|l|l|l|l|l|l|}
\hline No & Provinsi & Jumlah & $\begin{array}{l}\text { Sudah } \\
\text { Sertifikat Tanah }\end{array}$ & $\begin{array}{l}\text { Belum } \\
\text { Sertifkat Tanah }\end{array}$ & $\begin{array}{l}\text { Luas } \\
\text { Total (M2) }\end{array}$ \\
\hline 01 & Nanggroe Aceh Darus & 24.898 & 13.730 & 11.168 & $767.869 .011,58$ \\
\hline 02 & Sumatera Utara & 16.280 & 7.761 & 8.519 & $36.035 .460,00$ \\
\hline 03 & Sumatera Barat & 6.643 & 4.420 & 2.223 & $212.212 .380,00$ \\
\hline 04 & Sumatera Selatan & 6.394 & 3.521 & 2.873 & $380.456 .227,29$ \\
\hline 05 & Riau & 8.152 & 2.641 & 5.691 & $1.183 .976 .528,00$ \\
\hline 06 & Jambi & 5.918 & 3.785 & 2.133 & $13.516 .703,00$ \\
\hline 07 & Bengkulu & 2.759 & 1.869 & 890 & $7.122 .171,22$ \\
\hline 08 & Lampung & 14.591 & 8.372 & 6.219 & $22.990 .814,00$ \\
\hline 09 & Bangka Belitung & 1.133 & 779 & 354 & $3.243 .060,00$ \\
\hline 10 & Kepulauan Riau & 1.187 & 326 & 861 & $1.066 .799,00$ \\
\hline
\end{tabular}

19 Othman, R, Institusi Wakaf Sejarah Dan AmalanMasa Kini, Dewan Bahasa dan Pustaka, Kuala Lumpur waqf financing, 2015. 


\begin{tabular}{|l|l|l|l|l|l|}
\hline 11 & DKI Jakarta & 7.422 & 4.623 & 2.799 & $3.013 .640,00$ \\
\hline 12 & D.I Yogyakarta & 8.547 & 8.051 & 496 & $2.933 .943,00$ \\
\hline 13 & Jawa Barat & 74.860 & 45.873 & 28.987 & $116.662 .017,81$ \\
\hline 14 & Jawa Tengah & 103.294 & 82.641 & 20.653 & $163.169 .706,97$ \\
\hline 15 & Jawa Timur & 74.429 & 54.193 & 20.236 & $58.239 .272,20$ \\
\hline 16 & Banten & 20.089 & 11.049 & 9.040 & $39.322 .270,00$ \\
\hline 17 & Bali & 1.399 & 1.132 & 267 & $13.990 .000,00$ \\
\hline 18 & Kalimantan Barat & 4.467 & 2.257 & 2.210 & $27.544 .360,00$ \\
\hline 19 & Kalimantan tengah & 2.642 & 1.631 & 1.011 & $5.778 .500,00$ \\
\hline 20 & Kalimantan Selatan & 9.265 & 7.582 & 1.683 & $58.239 .272,20$ \\
\hline 21 & Kalimantan Timur & 3.423 & 772 & 2.651 & $13.984 .104,00$ \\
\hline 22 & Sulawesi Utara & 887 & 420 & 467 & $1.905 .272,70$ \\
\hline 23 & Sulawesi Tenggara & 2.386 & 1.516 & 870 & $5.225 .958,00$ \\
\hline 24 & Sulawesi Tengah & 3.173 & 2.051 & 1.122 & $165.042 .816,23$ \\
\hline 25 & Sulawesi Selatan & 10.440 & 5.486 & 4.954 & $1.029 .030 .278,00$ \\
\hline 26 & Sulawesi Barat & 2.448 & 571 & 1.877 & $3.251 .700,00$ \\
\hline 27 & Papua & 346 & 142 & 204 & $694,466,00$ \\
\hline 28 & Papua Barat & 338 & 105 & 233 & $591.117,00$ \\
\hline 29 & Nusa Tenggara Timur & 1.272 & 1.047 & 225 & $5.311 .787,00$ \\
\hline 30 & Nusa Tenggara Barat & 12.105 & 7.031 & 5.074 & $25.816 .325,00$ \\
\hline 31 & Maluku & 1.215 & 449 & 766 & $5.006 .359,00$ \\
\hline 32 & Maluku Utara & 1.489 & 605 & 543 & $30.223 .191,00$ \\
\hline 33 & Gorontalo & 1.877 & 729 & 1.148 & $1.663 .350,00$ \\
\hline Jumlah & 435.768 & 287.160 & 148.447 & $4.359 .443 .170,00$ \\
\hline
\end{tabular}

Sumber: Direktorat Pemberdayaan Wakaf Kementerian Agama RI (www.bwi.go.id)

Mengingat potensi wakaf tidak hanya berbentuk tanah melainkan bersumber dari donasi masyarakat, supaya menjadi relevan maka teori wakaf yang dilatarbelakangi teori perubahan sosial dan teori pembangunan. Perkembangan teori moneter dan perbankan menimbulkan hasil konsep wakaf tunai atau masyarakat menyebutnya wakaf uang ${ }^{20}$. Wakaf uang ini merupakan peluang besar untuk diinvestasikan pada negara, hal ini lebih memiliki nilai keuntungan dibandingkan wakaf tidak bergerak, Menurut Nasution (2006,43-44) potensi wakaf di Indonesia dengan jumlah dermawan dengan sebesar 10 juta jiwa dengan penghasilan Rp.10.000.000, maka akan terkumpul dan sekitar Rp. 3 triliun pertahun dari dana wakaf, maka jika bangsa ini mampu mengotimalkan potensi wakaf untuk kemakmuran dan kesejahteraan masyarakat. Perkembanganya Wakaf pada setiap tahunnya mengalami peningkatan maka dibutuhkannya Lembaga yang bergerak dalam perwakafan dan dibutuhkannya untuk pembinaan nazhir agar aset wakaf dikelola lebih baik dan lebih produktif sehingga bisa memberikan manfaat lebih besar kepada masyarakat, baik dalam bentuk pelayanan sosial, pemberdayaan ekonomi, maupun pembangunan infrastruktur publik, maka BWI hadir terbentuk dalam rangka mengembangkan dan memajukan perwakafan di Indonesia yakni Badan Wakaf Indonesia (BWI) adalah lembaga Negara independen yang dibentuk berdasarkan Undang-Undang

\footnotetext{
20 Taufiq, Yulizar D. Sanrego, Fiqih Tamkin : Membangun Modal Sosial dalam Mewujudkan Khairun Ummah,
} Jakarta : Qisthi Press, 2016. 
Nomor 41 Tahun 2004 tentang Wakaf, UU ini merupakan payung hukum perwakafan di Indonesia, dan untuk melengkapi Undang-undang tersebut, pemerintah juga telah menetapkan Peraturan Pemerintah nomor 42 tahun 2006 tentang pelaksanaan Undangundang nomor 41 tahun 200421.

\section{Kontribusi Kas wakaf untuk Pembangunan Sosial Ekonomi Masyarakat}

Kas wakaf merupakan alternatif penting dalam wakaf sistem. Hal ini tidak hanya diterapkan di Indonesia tetapi juga dipraktekkan di seluruh dunia, terutama di negaranegara mayoritas Muslim. Hal ini karena kas wakaf dapat menghasilkan pendapatan untuk mendukung kekurangan wakaf dana dalam rangka meningkatkan pembangunan masyarakat.

Baitul Mal sebagai lembaga pengelola keuangan negara yang terkait dengan penerimaan dan pengeluaran belanja negara telah dimulai sejak masa pemerintahan Rasulullah SAW. Pengelolaan Baitul Mal kemudian diteruskan oleh Daulah Islamiyah, hingga akhirnya kekhilafahan Islam runtuh pada tahun 1924 M. Baitul Mal pada masa Daulah Islamiyah merupakan lembaga atau institusi negara sebagai tempat dan pengelolaan dana umat dari pengumpulan sumber pendapatan hingga pengalokasian belanja negara sesuai dengan kaidah Islam. Data perkembangan pendapatan dan belanja negara di Indonesia terdapat dalam Anggaran Pendapatan dan Belanja Negara (APBN) yang berada di bawah Departemen Keuangan oleh Menteri Keuangan.

Konsep anggaran APBN modern sebenarnya bisa mengadopsi konsep Baitulmaal yang disebut balanced budget. Seimbang antara yang diterima dan yang dikeluarkan. Maka dari itu, meski utang diperbolehkan tapi tidak dianjurkan dalam Islam. Dalam pengelolaan keuangan negara Islam, Rasulullah Saw sebagai pemimpin selalu berusaha menerapkan kebijakan kebijakan yang tujuan akhirnya untuk kemaslahatn ummat. Prinsip utama yang Rasulullah SAW ajarkan adalah bagaimana menerapkan balanced budget. Pengaturan APBN yang dilakukan Rasulullah SAW secara cermat, efektif, dan efisien, sehingga jarang terjadinya defisit anggaran meskipun sering terjadi peperangan.

${ }^{21}$ Arifin, N. R, Manajemen Istibdal Atas Aset Wakaf (Doctoral dissertation, UNIVERSITAS AIRLANGGA), 2020. 


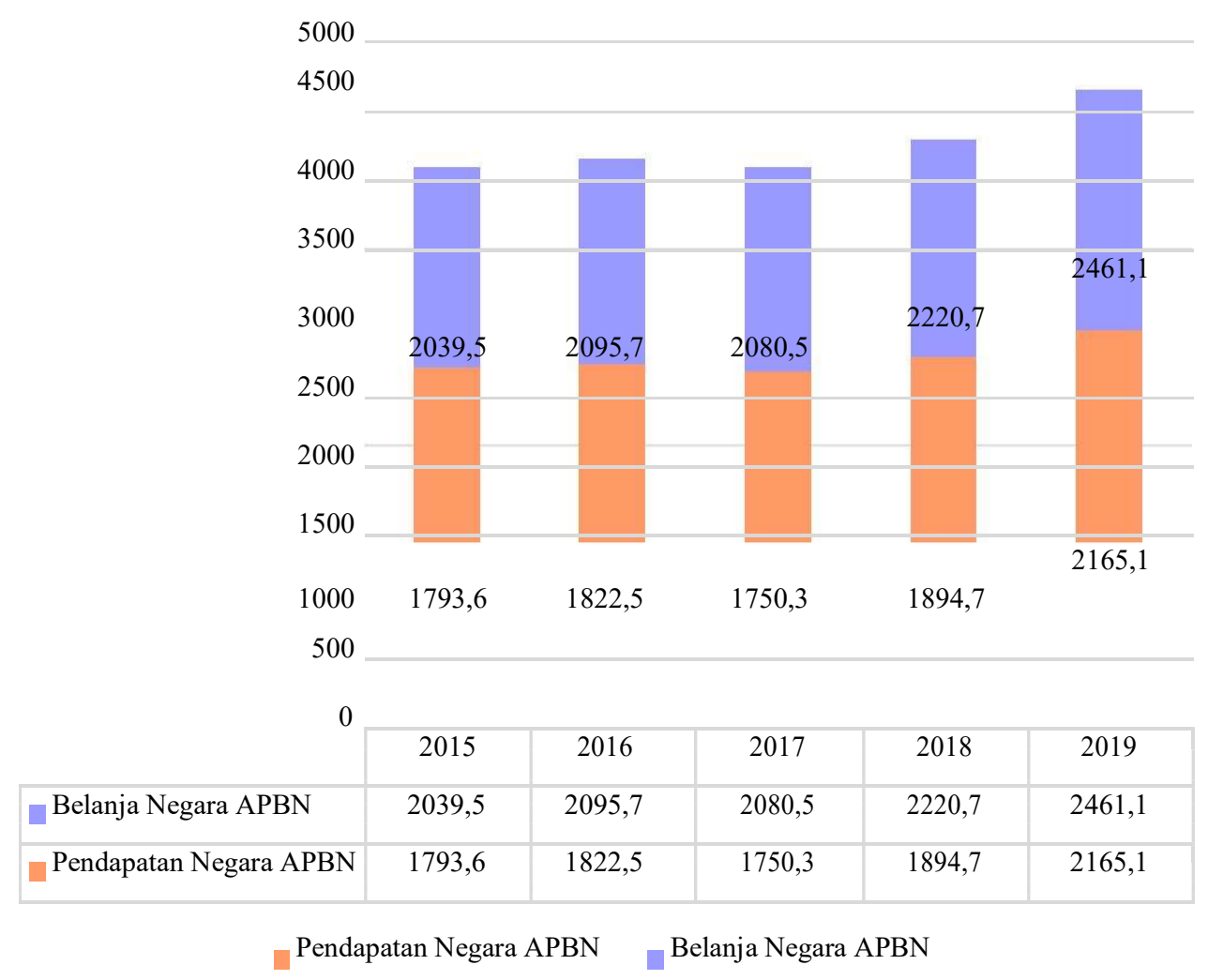

\section{Gambar 4.1 Perkembangan Pendapatan dan Belanja APBN Indonesia Tahun 2015 - 2019 (triliun rupiah)}

Sumber: Kementerian Keuangan RI (2019)

Berdasarkan Gambar diatas bahwa rata-rata pendapatan Indonesia mengalami peningkatan, walaupun terjadi penurunan pada tahun 2017 namun realisasi pendapatan negara pada tahun 2018 telah melampaui target APBN yakni sebesar $102,2 \%$ dan hal ini merupakan yang pertama kali sejak 2011. Realisasi pendapatan negara mencapai Rp1.942,3 triliun atau tumbuh sebesar $16,6 \%$ dan jauh lebih tinggi sebesar 7,1\% apabila dibandingkan pertumbuhan pada tahun 2017 (Kemenkeu, 2019). Adapun alur penyusunan APBN Indonesia yaitu Pemerintah bersama Dewan Perwakilan Rakyat (DPR) akan membahas dan menyepakati APBN dengan memperhatikan pertimbangan Dewan Perwakilan Daerah (DPR) RI.

Pemerintah akan menjalankan beberapa kebijakan pokok di dalam APBN tahun 2019 yaitu: pertama, mobilisasi pendapatan akan dilakukan secara realistis untuk menjaga iklim investasi tetap kondusif. Kedua, Belanja negara yang produktif akan 
diarahkan untuk mendorong peningkatan kualitas Sumber Daya Manusia (SDM), penguatan program perlindungan sosial, percepatan pembangunan infrastruktur, reformasi birokrasi, serta penguatan desentralisasi fiskal. Ketiga, efisiensi serta inovasi pembiayaan akan menjadi landasan dalam mencapai pertumbuhan ekonomi yang berkelanjutan. Selain itu, Pemerintah juga akan menyiapkan diri terhadap dinamika perekonomian global agar APBN dapat dijaga tetap sehat, adil, dan mandiri sehingga mempunyai daya ungkit terhadap perekonomian nasional 22.

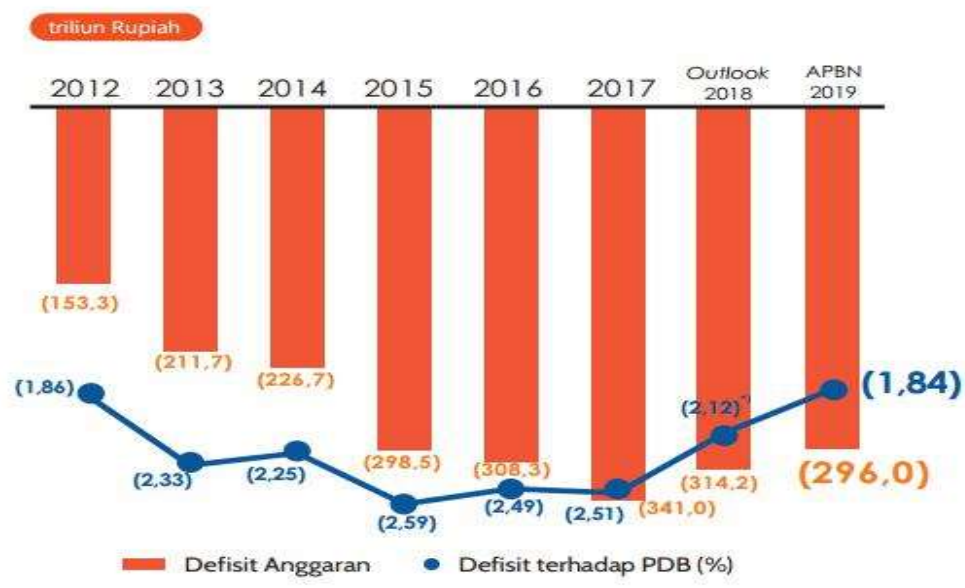

\section{Gambar 4.2 Rasio Defisit APBN Indonesia}

Sumber: Kementerian Keuangan RI (2019)

Berdasarkan Gambar defisit anggaran tahun 2019 adalah yang terendah sejak 2015. Hal ini diartikan bahwa perekonomian Indonesia mengalami pertumbuhan positif. Pemerintah Indonesia menggunakan kebijakan defisit sebagai alat untuk menstabilkan perekonomian. Menurut pemerintah, kebijakan utang bukanlah tujuan fiskal melainkan merupakan alat fiskal untuk menjaga momentum pertumbuhan ekonomi. Pembiayaan defisit melalui utang tersebut juga dibatasi oleh UndangUndang nomor 17 tahun 2003 tentang Keuangan Negara yang mengatur bahwa defisit APBN maksimum sebesar 3\% terhadap PDB dan rasio utang sebesar 60\% terhadap PDB. Pada tahun 2018, realisasi pendapatan negara melampaui target APBN $(102,2 \%)$ dan merupakan yang pertama kali sejak 2011. Realisasi pendapatan negara mencapai Rp1.942,3 triliun, atau tumbuh sebesar 16,6\% dan jauh lebih tinggi dibandingkan pertumbuhan pada tahun 2017 sebesar 7,1\% ${ }^{23}$.

22 Kementerian Keuangan 2019. Publikasi Laporan APBN 2019. Retrieved from https://www.kemenkeu.go.id/. Diakses 29 Mei 2019.

23 Kementerian Keuangan 2019. Publikasi Laporan APBN 2019. Retrieved from https://www.kemenkeu.go.id/. Diakses 29 Mei 2019. 


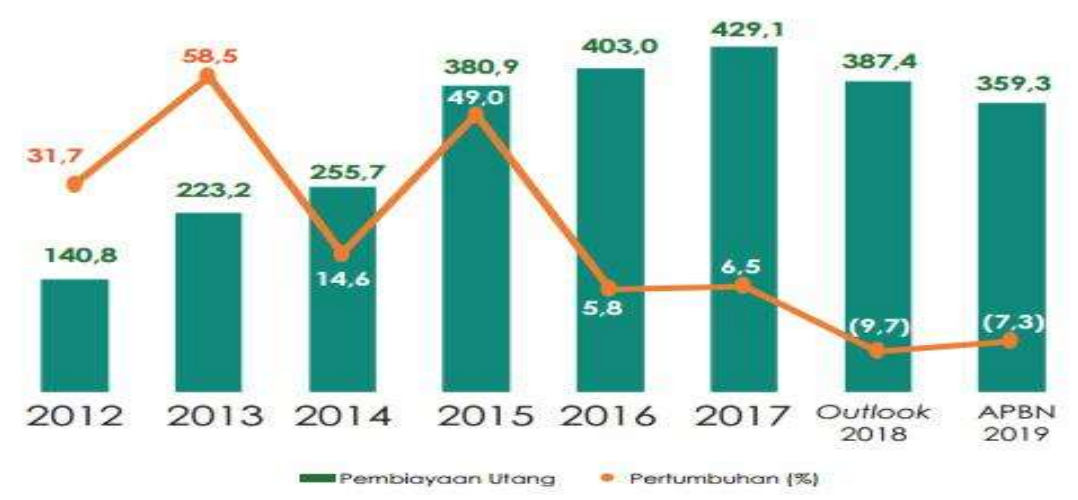

Gambar 4.3 Pembiayaan Utang Indonesia

Sumber: Kementerian Keuangan RI (2019)

Berdasarkan Gambar 4.3 terkait perkembangan pembiayaan utang Indonesia pada tahun 2017 hingga 2019 mengalami penurunan, sebagaimana hal ini tercermin dari rasio defisit APBN Indonesia. Kebijakan pembiayaan utang ini diambil dengan menimbang bahwa kebutuhan untuk pembangunan merupakan kebutuhan yang harus segera diwujudkan tanpa penundaan. Pemerintah sangat memegang teguh prinsip ini dan berkomitmen bahwa setiap rupiah utang yang dilakukan harus dimanfaatkan untuk membiayai kegiatan yang sifatnya produktif dan investasi dalam jangka panjang yang tidak dapat ditunda pelaksanaannya, seperti penyediaan fasilitas kesehatan dan ketahahan pangan. Penundaan pembiayaan justru akan mengakibatkan biaya/kerugian yang lebih besar di masa mendatang 24

Kesempatan pembiayaan pembangunan saat ini dioptimalkan untuk menutup gap penyediaan infrastruktur dan meningkatkan Indeks Pembangunan Manusia (IPM) Indonesia yang masih relatif tertinggal dibanding negara lain. Peningkatan IPM dapat dipenuhi antara lain melalui peningkatan sektor pendidikan, kesehatan, dan perlindungan sosial. Hal-hal ini menunjukkan bahwa utang Pemerintah melalui pembiayaan defisit digunakan dengan efisien untuk kesejahteraan rakyat, tidak hanya dalam jangka pendek (pengurangan subsidi) namun juga jangka panjang seperti infrastruktur, pendidikan, dan kesehatan ${ }^{25}$. Hal ini sesuai dengan Peraturan Presiden Nomor 18 tahun 2007 bahwa sasaran pembangunan ekonomi tahunan

\footnotetext{
24 Kementerian Keuangan 2019. Publikasi Laporan APBN 2019. Retrieved from https://www.kemenkeu.go.id/. Diakses 29 Mei 2019.

25 Kementerian Keuangan 2019. Publikasi Laporan APBN 2019. Retrieved from https://www.kemenkeu.go.id/. Diakses 29 Mei 2019.
} 
Indonesia diarahkan untuk mendorong pertumbuhan ekonomi dalam rangka memperluas lapangan pekerjaan dan mengurangi tingkat kemiskinan ${ }^{26}$.

Oleh karena itu telaah dalam pembahasan topik mengenai kebijakan fiskal dalam perspektif ekonomi Islam pada masa Rasulullah SAW dan Khulafaurasyidin dalam mengelola kebijakan fiskal yang berlandaskan prinsip Syariah telah terbukti membawa kepada kesejahteraan material dan spiritual. Selain itu adanya peranan wakaf dan zakat yang memiliki peluang sebagai instrumen fiskal yang diharapkan kebijakan fiskal di Indonesia mampu mengurangi pembiayaan utang, tetapi mengoptimalkan peranan instrumen filantropi dalam ekonomi Islam. Di sisi lain pentingnya mengetahui perkembangan kebijakan fiskal Indonesia saat ini sebagai langkah awal dalam mengevaluasi kinerja pemerintahan dalam mewujudkan kestabilan ekonomi nasional ditengah gejolak perekonomian global.

\section{Penerapan Intrumen Wakaf Mengurangi Pembiayaan Utang}

Spirit kuat bagi masyarakat Indonesia untuk penerapan konsep wakaf dalam pembiayaan publik dan publik camuran yang di dalamnya memberikan keluasan pada lembaga-lemabga nadzir untuk mengelola harta wakaf sesuai dengan khasanah lokal keislaman. Karena Indonesia sebagai populasi Muslim menjadi mayoritas, maka syariat Islam diIndonesia akan mudah dipahami oleh masyarakatnya bukan hanya dalam aspek ekonomi dab hukum, tetapi mencakup berbagai bidang lain, seperti Sosial, Budaya, Kepemerintahan.

Banyak tantangan dan permasalahan yang dihadapi dalam pengembangan gaya penerapan wakaf di Indonesia. Permasalahan yang muncul antara lain adalah rendahnya pemahaman masyarakat terhadap konsep wakaf. Tatkala pertumbuhan gaya hidup halal yang masif di negeri ini, faktor pemilihan penanaman cinta pada negara sendiri melalui penerapan wakaf sejak dini sebagai pilot project dalam hal pendukung atmosfer gaya hidup masyarakat sesuai tuntunan agama. Oleh karena itu, Hal ini dirasa cukup prospektif untuk menjadikan setiap rumah di Indonesia memiliki pemahaman atas pengelollan dan pnerapan konsep wakaf yang mana tidak terputus amal perbuatannya guna mencetak sumber daya insani berwawasan Nasionalis yang peduli pada negaranya dengan penerapan istrumen yang islami.

Pada saat kesadaran masyarakat Indonesia menyadari konsep wakaf sebagai pemasukan publik dalam mengumpulkan, secara tidak langsung akan terjadinya peningkatan pemahaman masyarakat dan memberikan kontribusi wakaf untuk pembiayaan barang publik murni dan campuran, terutama yang menjadi keunikan di Indonesia diesetip daerah telah dibentuk lembaga Nadzir yang mengelola wakaf jadi ketika struktur yang realistis dan praktis diletakkan di tempat. Struktur tersebut dapat

26 Kementerian Keuangan 2019. Publikasi Laporan APBN 2019. Retrieved from https://www.kemenkeu.go.id/. Diakses 29 Mei 2019. 
dikembangkan dengan memberikan solusi untuk masalah disorot dalam Bagian4. Untuk dimasukkan ke dalam sederhana, yang diwawancarai' Jawabannya dapat bertema ke dalam skema wakaf, modus investasi wakaf, hukum wakaf, tata kelola wakaf dan dokumentasi wakaf perbuatan.

\section{Penerapan Wakaf sebagai Kas Negara}

Wakaf tunai merupakan salah satu instrumen yang diperbolehkan diIndonesia oleh Fatwa Majlis Ulama Indonesia pada , tanggal 11 mei 2002 tentang rumusan definisi wakaf tentang perlunya dilakukan peninjauan dan penyempurnaan (pengembangan) definisi wakaf yang telah umum diketahui, dengan memperhatikan maksud hadis, antara lain, riwayat dari Ibnu Umar, Surat Direktur Pengembangan Zakat dan Wakaf Depag, nomor Dt.1.III/5/BA.03.2/2772/2002, tanggal 26 April 2002, belum lagi potensi tanah wakaf yang telah terdaftar di BWI (Badan Wakaf Indoneia), peran pemerintah dapat memanfaatkan dan mengembangkan harta wakaf yang dimiliki untuk diambil manfaatnya sebagai pemasukan Kas Negara, mengingat Indonesia memiliki harta wakaf berbentuk tanah yang terdaftar di BWI sejumlah 4.359.443.170,00.

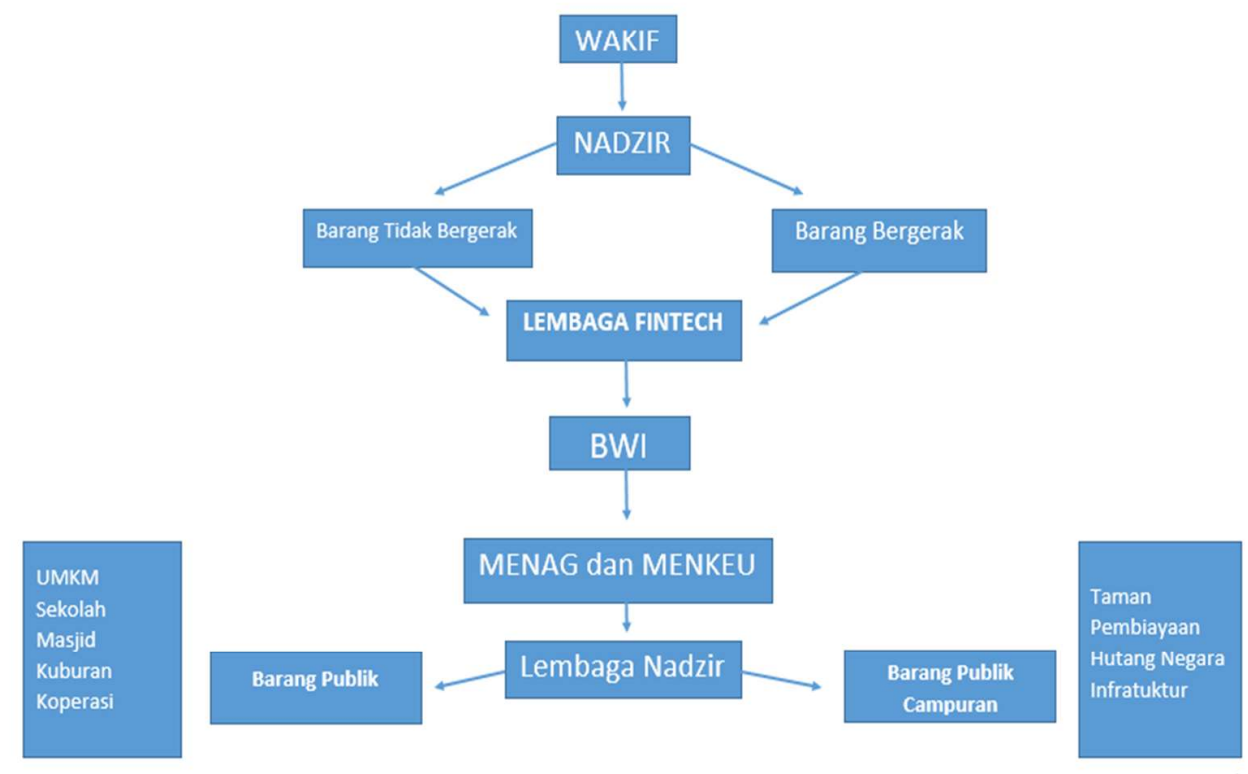

Sumber : Penulis mencoba membuat Ilustrasi konsep wakaf sebagai Barang publik dan barang publik campuran

Berdasarkan kondisi keadaan kepatuhan masyarakat Indonesia atas penerapan istrumen wakaf, dibutuhkan sebuah strategi guna meningkatkan pemahaman masyarakat agar sadar pada konsep wakaf. Strategi yang diterapkan ini harus bersifat menyeluruh dan menjawab semua tantangan juga permalahan yang ada. Pada intinya strategi ini dapat 
meningkatkan core competencies dari lembaga Nadzir Wakaf dan pada akhirnya meningkatkan daya saing dalam pengelolaanya, diantaranya ${ }^{27}$ :

a. Dukungan Pemerintah Daerah.

Dukungan pemerintah daerah akan berkembangnya pola penerapan konsep wakaf di setiap daerah dengan dikornidir dibawaha kementrian agama Kabupaten. Hal ini didasarkan oleh kewenangan yang bersifat pilihan yang dimiliki oleh pemerintah daerah sebagai daerah otonom sebagaimana yang diatur dalam di dalam Undang-Undang No. 23 Tahun 2014 Tentang Pemerintahan Daerah (yang untuk selanjutnya disingkat UU Pemda). Di dalam UU Pemda ini terdapat urusan yang menjadi kewenangan pemerintah daerah kabupaten/kota yang bersifat pilihan, yaitu di dalam Pasal 14 ayat 2 UU Pemda, yang berbunyi 28: "Urusan Pemerintahan kabupaten/kota yang bersifat pilihan meliputi urusan kepemerintahan yang secara nyata ada dan berpotensi untuk meningkatkan kesejahteraan masyarakat sesuai dengan kondisi, kekhasan, dan potensi unggulan daerah yang bersangkutan". Sehingga butuh Regulasi Legislasi dari pemerintah daerah tentang pengembangan pendidikan ekonomi syariah atau pendidikan ekonomi berbasis Islam di tataran pendidikan dasar dan menengah atas kesesuaian kearifan lokal yang agamis.

b. Model Pengaturan Regulasi di Daerah

Apabila berbicara Pemerintah Daerah, telah terjadi perubahan yang sangat mendasar sejak di syahkannya UU No. 32 tahun 2004 yang kemudian disempurnakan menjadi UU No. 23 tahun 2014 tentang Pemerintahan Daerah. Hal mendasar dalam perubahan terletak pada hubungan antara Pemerintah Pusat dengan Pemerintah Daerah yang luas, nyata, dan bertanggung jawab. Konsekuensinya pemerintah daerah harus benar-benar menfaatkan situasi ini dengan mengoptimalkan berbagai potensi dan kearifan lokal yang ada. Sedangkan sementara ini ada beberapa Perda Syariah dan formalisasi tuntutan Syari'at Islam yang juga diwujudkan melalui kebijakan pemerintah daerah yang berbentuk Surat Keputusan, Instruksi maupun Surat Edaran Bupati/Wali Kota. Yang setidaknya ada kesesuaian dengan penerapan Perda Syariah terhadap penerapan konsep wakaf.

c. Menambahkan Value Added pada Lembaga Nadzir wakaf diIndoenesia.

Value added yang perlu ditambahkan pada lembaga Nadzir wakaf untuk mengelola harta wakaf secara efisien dan tidak mengurangi pokok dari harta wakaf dapat dengan edukasi untuk lebih memahami Islam secara Kaffah dalam bidang ekonomi. Selain itu, akan menguatkan fondasi SDM perekonomian yang berkarakter dan berakhlaqul karimah. Sehingga kesejahteraan akan tercipta secara merata.

27 Arifin, N. R., Muhtadi, R., \& Aziz, A, Manajamen Istibdal Atas Aset Wakaf Sebagai Pembangunan Ekonomi. Filantropi: Jurnal Manajemen Zakat dan Wakaf, 1(2), 193-216, 2020.

28 Marijul ikhwan dkk, Pengaturan Hukum Pengetahuan Tradisional Sebagai Upaya Perlindungan Kearifan Lokal Madura Oleh DPRD Bangkalan, Jurnal Yustisia edisi 85 2013, 72, 2013. 
Tentu saja penerapan konsep wakaf menjadi langkah awal dibentuknya Perda Syariah semacam ini tetap menghadapi beberapa rintangan laten. Misalnya, harus bersinerginya seluruh elemen yang ada khususnya Pemerintah, Akademisi dan Praktisi pelaku lembaga Nadzir, pelaku industri dan usaha ekonomi syariah. Karena peningkatan pemasukan harta wakaf akan meningkatkan potensi pemasukan Kas negara dan menjadikan setiap daerah tidak bergantungan pada anggaran Negara, peningkatan ini juga menandakan besarnya penerapan konsep wakaf terhadap perekonomian secara keseluruhan. Industri dengan pangsa pasar yang besar akan memiliki market demand yang besar pula, dari sinilah kebutuhan SDM tenaga kerja ini dapat terpenuhi apabila pemerataan ekkonomi melalui konsep wakaf berjalan dengan telah sesuai mu'amalah islamiyah.

Peningkatan pemahaman masyarakat atas wakaf akan membuat perekonomian Indonesia lebih inklusif karena pertumbuhan secara merata. Lebih dari itu, hal ini akan meningkatkan fondasi perekonomian daerah-daerah di Indonesia yang berujung pada peningkatan daya saing global. Wallahua'lam bisshowab.

\section{KESIMPULAN}

- Konsep wakaf tidak hanya melihat penerapan secara historis saja, sistem penerapan wakaf di Indonesia didominasi harta wakaf yang berbentuk sekolah, masjid, dan kuburan, sehingga perlu adanya pengembangan harta wakaf secara produktif yang dapat digunakan negara

- Pada intinya strategi ini dapat meningkatkan core competencies dari lembaga Nadzir Wakaf dan pada akhirnya meningkatkan daya saing dalam pengelolaanya, diantaranya:

1. Dukungan Pemerintah Daerah.

2. Model Pengaturan Regulasi di Daerah

3. Menambahkan Value Added pada Lembaga Nadzir wakaf diIndoenesia.

\section{DAFTAR PUSTAKA}

Aby Zain Ibnu, (2016) Fathul Qarīb 3 Bahasa, Kediri : Zamzam Sumber Mata Air Ilmu. Andreassen A., Bard. "Human Rights and Legal Empowerment of the Poor", Extreme Poverty and Human Rights Expert Seminar, Geneva 23-24 February 2007, Norwegian Centre for Human rights, University of Oslo.

Arditi, Benjamin. "From Globalism to Globalization: The Politics of Resistance", New Political Science, Volume 26, Number 1 (March 2004): 1-18. 
Arifin, N. R. (2020). Manajemen Istibdal Atas Aset Wakaf (Doctoral dissertation, UNIVERSITAS AIRLANGGA).

Arifin, N. R., Muhtadi, R., \& Aziz, A. (2020). Manajamen Istibdal Atas Aset Wakaf Sebagai Pembangunan Ekonomi. Filantropi: Jurnal Manajemen Zakat Dan Wakaf, 1(2), 193216.

Axford, Barrie. The Global System, Politics and Culture. New York: St. Martin \& rsquoss Press, 1995.

Babacan, M. (2011), "Economics of philanthropic institutions, regulation and governance Turkey", Journal of Economic and Social Research, Vol. 13 No. 2, pp. 61-89.

Brealey, R.A., Myers, S.C. and Allen, F. (2011), Principles of Corporate Finance, McGraw Hill Irwin, New York, NY.

Çizakça, M. (2000), A History of Philanthropic Foundations: The Islamic World from the Seventh Century to the Present, Bogazici University Press, Istanbul

Direktorat Pemberdayaan Wakaf Kementrian Agama RI (2019). Retrieved from https://www.bwi.or.id/. Diakses 29 Mei 2019.

Geertz, Clifford. "Religion: Anthropological Study", in David L. Sills (ed.) International Encyclopedia of the Social Sciences. London: Collier-Macmillan Publishers, 1965: 220.

Gil, M. (1998), “The earliest waqf foundations”, Journal of Near Eastern Studies, Vol. 57 No. 2, pp. 125-140.

Kahf,M. (2014), Islamic Economics: The Charitable Sector, Ad Dawhah, Qatar.

Karim, A. (2017). Ekonomi Makro Islam. Jakarta: PT. Rajawali Press..

Kementerian Keuangan. (2019). Publikasi Laporan APBN 2019. Retrieved from https://www.kemenkeu.go.id/. Diakses 29 Mei 2019.

Kementerian Keuangan. (2019). Publikasi Laporan Realisasi APBN 2019. Retrieved from https://www.kemenkeu.go.id/informasi-publik/realisasi-apbn/. Diakses 29 Mei 2019

Kuran, T. (2001), "The provision of public goods under Islamic law: origins, impact, and limitations o the waqf system", Law\& Society Review, Vol. 35 No. 4, pp. 841-898.

Marijul ikhwan dkk, (2013) Pengaturan Hukum Pengetahuan Tradisional Sebagai Upaya Perlindungan Kearifan Lokal Madura Oleh DPRD Bangkalan, Jurnal Yustisia edisi 85 2013, 72

Mohsin, M.I.A. (2009), CashWaqf: A New Financial Product, 1st ed., Pearson Malaysia Sdn Bhd, Kuala Lumpur.8 
Mohsin, M.I.A. (2013), "Financing through cash waqf: a revitalization to finance different needs", International Journal of Islamic and Middle Eastern Finance and Management, Vol. 6 No. 4, pp. 304-321.

Othman, R. (2015), InstitusiWakaf Sejarah Dan AmalanMasa Kini, Dewan Bahasa dan Pustaka, Kuala Lumpur waqf financing

Pudjo, S. (2006) Pro Kontra Implementasi Perda Syariah (Tinjauan Elemen Masyarakat), Jurnal Al=Mawarid Edisi 16 tahun, 231

Sabiq S, (2013) Fiqih Sunnah 5, Jakarta : Tinta Abadi Gemilang.

Taufiq, Yulizar D. Sanrego, (2016), Fiqih Tamkin : Membangun Modal Sosial dalam Mewujudkan Khairun Ummah, Jakarta : Qisthi Press. 